\title{
O modus operandi do Regime Fiscal Brasileiro
}

\section{Wander Marcondes Moreira Ulhôa'}

\begin{abstract}
Resumo:
O propósito deste artigo é mostrar que o Regime Fiscal Brasileiro deve ser entendido com base nas diretrizes do Regime Macroeconômico, afinal, o objetivo é o cumprimento das metas fiscais (superávit primário) no sentido de manter estável a trajetória da dívida pública/PIB. Nesse sentido, pode-se afirmar que a Lei de Responsabilidade fiscal - LRF é o ordenamento jurídico de maior abrangência no Regime Fiscal, pois cumpre papel bastante distinto daqueles pretendidos pela Constituição Federal e pela Lei 4.320/1964. Destaca-se, finalmente, que a flexibilização das regras fiscais e a reversão do ciclo econômico desencadearam fortes desajustes das contas públicas das esferas subnacionais.

Palavras-chave: Regime Macroeconômico e Fiscal; Lei de Responsabilidade Fiscal (LRF); Esferas Subnacionais.
\end{abstract}

\section{The Modus Operandi of the Brazilian Fiscal Regime}

\begin{abstract}
:
The purpose of the article is to show that the Brazilian Fiscal Regime must be understood from the guidelines of the Macroeconomic Regime, after all the objective is the fulfillment of the fiscal targets (primary surplus) in order to maintain stable the public debt / GDP trajectory. In this sense, it can be stated that the LRF is the most comprehensive legal system in the Fiscal Regime, since it fulfills a very different role from those intended by the Federal Constitution and Law 4,320 / 1964. Finally, it is worth noting that the flexibilization of fiscal rules and the reversal of the economic cycle have triggered strong misalignments of the public accounts of the subnational spheres Keywords: Macroeconomic and Fiscal Regime; Fiscal Responsibility Law (FRL); Subnational Spheres.
\end{abstract}

Classificação JEL: H68, H83

\section{Introdução}

O regime fiscal brasileiro é resultado de um ambiente político e macroeconômico liberal que emergiu em meados da década de 1990, cujos esforços da ação estatal se centraram na estabilização monetária, com ênfase nas regras monetárias

1 Doutor em Economia pela Universidade Federal de Uberlândia. Secretário de Governança Financeira Orçamento da Prefeitura Municipal de Coronel Fabriciano. E-mail: wulhoa@yahoo.com.br 
(metas de inflação) e nas fiscais (equilíbrio orçamentário e superávit primário). Eis que se estabelecem, então, as diretrizes do regime macroeconômico, garantindo um guia às ações do Estado, independentemente da matriz ideológica dos gestores públicos.

Nesse contexto, deve-se entender a construção do regime fiscal brasileiro, especialmente a sanção da Lei de Responsabilidade Fiscal (LRF), que fixou regras orçamentárias e fiscais para os entes federativos no intuito de garantir o equilíbrio das contas públicas e de obstar a ação perdulária do Estado, quesito imprescindível para a estabilidade monetária. Pretendia-se, essencialmente, que o ordenamento jurídico restringisse as ações estatais nas diversas esferas públicas, reduzindo a margem de manobra do Estado para guiar o processo de desenvolvimento - isso explica o ímpeto na fixação de regras fiscais, subordinando os instrumentos de natureza fiscal, particularmente os gastos primários e as receitas, à necessidade de garantir um ambiente institucional adequado para a valorização do capital financeiro, o que contribuiu para ancorar as expectativas dos agentes econômicos.

Analisando os diversos dispositivos da LRF, fica claro que o "equilíbrio das contas públicas" é construído pelo cumprimento das metas fiscais com vistas à geração de superávit primário. Isso explica as razões pelas quais a LRF estabeleceu normas, regras e parâmetros para as finanças públicas da União, dos estados e dos municípios, no sentido de "prevenir riscos" e de "corrigir desvios". Daí emergiram, por exemplo, os parâmetros para as despesas de pessoal, o endividamento público e as inscrições em restos a pagar, assim como a imposição de regras de convergência quando tais parâmetros fossem ultrapassados.

É notório que o bom desempenho do ciclo econômico, a partir de 2005, possibilitou a expansão das despesas públicas primárias, permitindo cumprir, ainda que alguns dispositivos da LRF fossem flexibilizados, as regras orçamentárias e fiscais. O problema ocorre quando o incremento da despesa se torna incompatível com a geração de excedente fiscal (superávit primário). Esse cenário é tanto pior quanto mais intensa é a reversão do ciclo econômico, pois o nível de receita é insuficiente para suportar o incremento da despesa primária e, pari passu, manter as exigências das metas fiscais.

Os efeitos desse desarranjo repercutiram em todo setor público brasileiro, mas os desequilíbrios das contas públicas das esferas subnacionais são ainda mais intensos devido à rigidez das despesas primárias e aos elevados encargos financeiros. Argumenta-se, ainda, que os desequilíbrios fiscais das esferas subnacionais não podem ser relacionados apenas à reversão do ciclo econômico, como também às decisões políticas com pouca ou nenhuma aderência às regras orçamentárias e fiscais.

Com vistas a evidenciar os argumentos expostos acima, este artigo será composto por três seções, além desta introdução e das considerações finais. A segunda seção tem por objetivo mostrar a matriz teórica do regime fiscal brasileiro e seus pressupostos, os quais somente podem ser entendidos com base no regime macroeconômico. A terceira seção apresenta os principais dispositivos da LRF, enfatizando 
as despesas de pessoal, o endividamento e os restos a pagar. Destaca-se, ainda, a flexibilização dos dispositivos que permitiram compatibilizar o aumento das despesas primárias com cumprimento das metas fiscais (superávit primário). Finalmente, na quarta seção, evidencia-se que a origem dos desequilíbrios das esferas subnacionais não se explica apenas pela reversão do ciclo econômico, mas também pela negligência às regras fiscais e orçamentárias.

\section{A matriz teórica do regime fiscal brasileiro}

Entender o regime fiscal brasileiro numa visão apenas do ordenamento jurídico é insuficiente, embora necessário. Há de se reconhecer, então, que o pano de fundo do processo diz respeito a restringir a ação do Estado como provedor de serviços públicos e como instituição de coordenação das expectativas dos agentes econômicos. O sentido desse regime está voltado a estabelecer determinados regramentos fiscais que permitam reduzir, o tanto quanto possível, as ações discricionárias dos gestores públicos, garantindo um guia às ações de um Estado independente da matriz ideológica. Supõe-se que os instrumentos fiscais que outrora foram importantes para atenuar as flutuações do ciclo econômico se convertam, agora, em âncora para garantir a solvência do Estado por intermédio da estabilidade dívida/PIB.

Nessa perspectiva, o regime fiscal pressupõe reduzir a abrangência do Estado, garantindo um ambiente institucional estável e adequado às relações privadas e convergentes com as premissas do regime macroeconômico, permitindo ancorar as expectativas dos investidores privados com base em regras monetárias (Sistema de Metas de Inflação) e fiscais (superávit primário e nível de endividamento). Assim, os fundamentos fiscais são importantes, inter alia, para que sejam capazes de atender aos princípios do regime macroeconômico.

No caso brasileiro, o regime macroeconômico está ancorando na visão do mainstream, podendo ser resumido naquilo que se convenciona chamar na literatura especializada de Novo Consenso Macroeconômico (NCM). Os pressupostos dessa corrente estão ancorados nas escolas monetárias Novo-Clássica, Ciclo Real de Negócios e dos Novos Keynesianos, cujo eixo central da política econômica é a estabilidade monetária. Desse modo, a política monetária, com a fixação da taxa de juros de curto prazo, exerce a primazia em relação às demais políticas econômicas fiscal, cambial e financeira. De acordo com Mishkin (2011, p. 2-3), os princípios do NCM podem assim ser sintetizados:

1) inflation is always and everywhere a monetary phenomenon; 2) price stability has important benefits; 3) there is no long-run tradeoff between unemployment and inflation; 4) expectations play a crucial role in the determination of inflation and in the transmission of monetary policy to the macroeconomy; 5) real interest rates need to rise with higher inflation, i.e., the Taylor Principle; 6) monetary policy is subject to 
the time-inconsistency problem; 7) central bank independence helps improve the efficiency of monetary policy; 8) commitment to a strong nominal anchor is central to producing good monetary policy outcomes; and 9) financial frictions play an important role in business cycles.

É por isso, então, que a estabilidade monetária está no centro do regime macroeconômico, que, no Brasil, baseia-se no chamado Tripé Macroeconômico, a saber: metas de inflação, câmbio flutuante e superávit primário. Em cronologia, o primeiro passo para a construção desse regime foi o Decreto n. 3.088, de 21 de junho de 1999, que estabeleceu a sistemática das metas de inflação (BRASIL, 1999). Trata-se de uma regra monetária que passou a guiar o espectro da política monetária, tendo subordinado as demais dimensões da política econômica aos seus imperativos.

Nesse contexto, as ações do Estado são conduzidas com o propósito de alcançar, de sancionar e de promover aqueles objetivos, cujo pressuposto para a gestão da autoridade monetária é o sucesso da estabilidade monetária, que depende do equilíbrio das contas públicas. O oposto também é válido, ou seja, desequilíbrios fiscais enfraquecem os instrumentos de política monetária, favorecendo a expansão dos preços. Ambos os cenários são previstos pela autoridade monetária:

Outro ponto importante sobre o combate à inflação, abordado na literatura e que está de acordo com as melhores práticas internacionais, diz respeito à adoção de um desenho de política fiscal consistente e sustentável, de modo a permitir que as ações de política monetária sejam plenamente transmitidas aos preços [...] Conforme ressaltado no Relatório de Inflação de setembro de 2015, e consistente com as discussões a respeito do Orçamento Geral da União para 2016 feitas à época, alterações significativas na trajetória esperada para as variáveis fiscais impactaram não apenas as hipóteses de trabalho contempladas nas projeções de inflação, mas também o próprio processo de apreçamento de ativos e a percepção de risco da economia doméstica, contribuindo para a deterioração das avaliações sobre o ambiente macroeconômico no médio e no longo prazo e da confiança dos agentes econômicos (BACEN, 2016, p. 2-5).

Percebe-se forte reciprocidade entre os regimes macroeconômico e fiscal. Com isso, é possível inferir que a desconstrução dos fundamentos fiscais não faz sentido, pois sua abrangência transcende o objetivo de manter a estabilidade monetária, sendo também "âncora" das expectativas dos agentes econômicos, o que afeta o preço dos ativos. Apreende-se que a prioridade do regime fiscal brasileiro é gerar superávits primários, o que garante equilíbrio das contas públicas suficiente para atender a uma trajetória sustentável do endividamento público.

Assim, as regras fiscais são elementos imprescindíveis que têm por objetivo impedir a ação perdulária do Estado, e a legislação orçamentária fiscal passa a incorporar um conjunto de metas, a partir do "Anexo de Metas Fiscais", que pretende estabelecer parâmetros adequados ao cumprimento do superávit primário, garantindo a sustenta- 
bilidade intertemporal da dívida pública. As demais variáveis (receita e despesa), que também compõem o anexo, deverão necessariamente convergir esforços para a consecução do referido superávit. Há, portanto, hierarquia de prioridades, cuja primazia é do superávit primário, não apenas porque é o principal indicador no que se refere à capacidade do Estado de honrar os compromissos financeiros derivados do estoque da dívida pública, mas também pelo fato de ele se encontrar no vértice do regime macroeconômico. Em outras palavras, o superávit primário não é um compromisso apenas do regime fiscal, mas ainda do macroeconômico.

Constata-se, portanto, que o arcabouço institucional do regime fiscal converge prioritariamente para manter a solvência do Estado, sem se preocupar com as demais variáveis macroeconômicas (emprego, renda, investimento, entre outras). No texto da Lei de Diretrizes Orçamentárias (LDO) da União de 2016, há clara referência à necessidade de garantir a sustentabilidade da dívida pública:

Nesse sentido, anualmente, são estabelecidas metas de resultado primário no intento de garantir as condições econômicas necessárias para a manutenção do crescimento sustentado, o que inclui a sustentabilidade intertemporal da dívida pública (BRASIL, 2015).

Infere-se que o conjunto de regras fiscais nada mais é do que a imposição de limites às ações do Estado, com o escopo de estimular a demanda agregada e de gerar efeitos virtuosos no nível do investimento e do emprego. No âmbito do mainstream, os efeitos dessas políticas são contraproducentes e causadores dos déficits orçamentários que são financiados por emissão monetária, gerando apenas o incremento nas taxas de inflação. Assim, o equilíbrio das contas públicas é pressuposto à estabilidade de preços, criando um obstáculo para a possibilidade de "dominância fiscal".

A ação do Estado, por meio da austeridade fiscal, deve favorecer a condução da política monetária, considerando que o objetivo é sempre a estabilidade de preços. Logo, num contexto em que a inflação é sempre (e em todo lugar) um fenômeno monetário, o equilíbrio das contas públicas é per se um instrumento que reforça a condução virtuosa da política monetária e amplia a confiança dos agentes privados (MONTES; ALVES, 2012). Além disso, a política fiscal perde relevância como instrumento de distribuição de renda e riqueza, preocupando-se com variáveis que se associam à preservação da riqueza financeira - é o caso, por exemplo, da relação/dívida e PIB e do superávit primário.

Pelo exposto, depreende-se que a condução da política monetária não pode alcançar objetivos e metas plenamente. Sem o apoio de uma política fiscal austera, o equilíbrio das contas públicas cumpre o papel de obstar a expansão da base monetária, gerando efeitos virtuosos na estabilidade monetária para abrir espaço no orçamento com a redução das despesas primárias para que o excedente de recursos fiscais - superávit primário - seja suficiente para manter a relação entre dívida e PIB em patamares adequados. Nesse entremeio, a austeridade fiscal cumpre o papel de absorver/neutra- 
lizar as despesas financeiras decorrentes do manejo da política monetária (por meio da taxa de juros de curto prazo) e da política cambial (via custos de manutenção das reservas internacionais e, recentemente, das operações swaps cambiais).

Sendo assim, pode-se inferir que a sanção da LRF não é simplesmente um arcabouço jurídico no âmbito fiscal, mas resultado de um ambiente político e macroeconômico liberal que emergiu nos anos de 1990 e que relegou o papel do Estado no processo de desenvolvimento, engendrando um desenho institucional em que ele cumpre funções complementares e/ou corretivas, com ênfase nos objetivos monetários via estabilização de preços e financeiros. A esse respeito, Lopreato (2014, p. 232) afirma que a “[...] revisão do papel do Estado tornou-se o pilar do novo regime fiscal. O projeto de viés liberal promoveu importante reestruturação patrimonial e retirou espaço da ação estatal ao transferir para o setor privado a tarefa de dinamizar a economia".

Eis o contexto em que deve ser inserida a LRF, garantindo, assim, um guia às ações do Estado através de rígidas regras fiscais, subordinando a execução orçamentária às necessidades do cumprimento das metas fiscais. Nesse cenário, o resultado primário será alçado para além da política fiscal, pois o bom funcionamento da política econômica (metas de inflação e câmbio flutuante) deverá disponibilizar, necessariamente, excedente fiscal (superávit primário) para acomodar as variações do estoque da dívida pública causadas pelo manejo da política monetária e cambial. Assim,

[...] a política fiscal, nessa perspectiva, incorporou o papel de fiadora do espaço de valorização do capital e de responsável por afastar o risco de default da dívida pública. O clamor favorável à consolidação fiscal virou lugar comum e mostrou-se parte inescapável da busca por credibilidade da política econômica [...] $\mathrm{Na}$ fase das finanças globalizadas não era suficiente se ater a ideia de redução dos déficits públicos, mas ir à frente, pensando no tempo de valorização da riqueza financeira; o que exigia estar atento ao movimento intertemporal das contas públicas, pois as alterações aí existentes influenciam as expectativas de ganho e as decisões de alocação das aplicações financeiras. A evolução da relação dívida/PIB, por sinalizar, com antecedência, o comportamento fiscal e as condições de financiamento público, transformou-se no parâmetro usado na definição da programação financeira e das ações na área fiscal (LOPREATO, 2005, p. 185).

Observa-se, portanto, que o resultado das contas públicas é dado pela capacidade de manter estável a relação dívida/PIB. Isso explica inter alia a razão de ser da LRF. Tanto é assim que, no Memorando de Política Econômica, enviado ao Fundo Monetário Internacional - FMI em 1998, já se evidenciava a necessidade de autorizar os gastos primários se (e somente se) estivesse garantida a meta de superávit estabelecida. Nesse contexto, adotou-se: 
[...] uma meta obrigatória para o superávit primário do governo federal além da criação de uma comissão interministerial de alto nível responsável inter alia pela garantia de consecução dessa meta, [assim] espera-se que estes superávits primários crescentes detenham o crescimento da dívida pública líquida em relação ao PIB por volta de 2000 (MINISTÉRIO DA FAZENDA, 1998, p. 3, grifos nossos).

Nessa visão de mundo, tencionava-se reduzir a abrangência da ação do Estado e, portanto, das políticas públicas convencionais, de modo que os recursos fiscais fossem suficientes para suportar os custos do processo de estabilização monetária e da estabilidade da dívida pública. É por isso que as políticas públicas de longo prazo perdem espaço, assim como as estruturas de planejamento e os aparatos institucionais do Estado vinculados à elaboração e execução das ações de governo, desmobilizados em favor das decisões tomadas na órbita do mercado - isso ocorre em quase todas as dimensões do Estado brasileiro a partir de 1990. Eis o contexto de discussão e aprovação da LRF.

Em síntese, deve-se entender a construção do regime fiscal brasileiro, especialmente com a sanção da Lei de Responsabilidade Fiscal (LRF), que fixou regras orçamentárias e fiscais ao setor público brasileiro no intuito de garantir inter alia o equilíbrio das contas públicas e de impedir a ação perdulária do Estado, quesito imprescindível à estabilidade monetária. Os dispositivos previstos no âmbito daquela legislação devem ser vistos com base nesse contexto. É o que doravante vamos mostrar.

\section{O modus operandi da Lei de Responsabilidade Fiscal}

A Lei Complementar n. 101, de 4 de maio de 2000, também denominada como Lei de Responsabilidade Fiscal (LRF), modificou de forma abrangente $o$ modus operandi do setor público brasileiro, na medida em que instituiu normas, regras e parâmetros para as finanças públicas - União, estados e municípios - no sentido de "prevenir riscos", "corrigir desvios" e, notadamente, garantir o "equilíbrio das contas públicas” por meio das metas estabelecidas. Da mesma forma, argumenta-se que ela restringiu (mas não suprimiu) o espectro de manejo da política fiscal, sobretudo nos quesitos: expansão da despesa, renúncia de receitas, relações do poder executivo com as empresas e bancos estatais, gastos de pessoal e endividamento público, ao estabelecer limites máximos e regras de transição para as Unidades da Federação (UFs) que se encontravam com indicadores fiscais além dos limites utilizados.

Assim, os efeitos mais imediatos foram sentidos pelas esferas subnacionais, notadamente os estados, que foram obrigados a aceitar os dispositivos estabelecidos na LRF. A ponta de lança desse processo foi a Lei n. 9.496, de 11 de setembro de 1997 (BRASIL, 1997), que estabeleceu critérios para a consolidação, a assunção e o 
refinanciamento, pela União, da dívida pública mobiliária de responsabilidade dos estados e do Distrito Federal, exigindo como contrapartida metas ou compromissos $\left(\operatorname{art.} 2^{\circ}\right)$ quanto às despesas com funcionalismo público, reforma administrativa, privatizações, resultado primário, entre outros.

Vista nessa perspectiva, a LRF pretende convergir as ações das esferas subnacionais, sobretudo aquelas relacionadas aos resultados fiscais, aos imperativos do Governo Federal. Nesse sentido, tenciona-se uma harmonização da política fiscal guiada, naturalmente, pelos objetivos estabelecidos em âmbito federal, cujo parâmetro é o resultado primário por excelência.

$\mathrm{Na}$ verdade, o resultado primário tem enorme importância no escopo da LRF, pois vários preceitos observados nessa legislação são condicionados por tal resultado. A programação orçamentária, por exemplo, é guiada pelo resultado primário estabelecido no Anexo de Metas Fiscais, de maneira a compatibilizar a arrecadação de receitas com as despesas, com vistas a alcançar a meta estabelecida do resultado primário. Não é sem razão que a LRF contém diversos dispositivos (art. $5^{\circ}, \mathrm{I}$; art. $\left.8^{\circ}\right)$ cujo objetivo é garantir os instrumentos necessários para o cumprimento da meta fiscal, estabelecendo as medidas cabíveis quando do descumprimento das metas:

[...] se verificado, ao final de um bimestre, que a realização da receita poderá não comportar o cumprimento das metas de resultado primário ou nominal estabelecidas no Anexo de Metas Fiscais, os Poderes e o Ministério Público promoverão, por ato próprio e nos montantes necessários, nos trinta dias subsequentes, limitação de empenho e movimentação financeira, segundo os critérios fixados pela lei de diretrizes orçamentárias (BRASIL, 2000).

A realização de receita, dentre vários outros indicadores, é obtida por meio do Relatório Resumido da Execução Orçamentária (RREO), art. 53, publicado bimestralmente, cujo objetivo precípuo é aferir se a gestão orçamentária e financeira condiz com as metas fiscais estabelecidas. Cumpre função semelhante, mas incorpora outros indicadores, por exemplo, a despesa de pessoal e o montante da dívida consolidada e mobiliária, além do Relatório de Gestão Fiscal (RGF), arts. 54 e 55, também publicado quadrimestralmente. Considera-se que tais indicadores não são uma opção, mas uma imposição da LRF, e o caso mais emblemático é o resultado primário, regra fiscal com maior abrangência no regime fiscal brasileiro.

Pode-se, assim, afirmar que a execução orçamentária é variável de ajuste e obedece aos imperativos do resultado primário, de modo que o indicativo de que as metas não serão alcançadas deverá, compulsoriamente, desencadear uma série de medidas no sentido de adequar a execução orçamentária às disponibilidades financeiras. Ora, se a execução orçamentária é incompatível com a receita efetivamente arrecadada, considerando que a meta fiscal não poderá ser alterada, há duas alternativas: contingenciar as despesas (limitação de empenho) ou aumentar as receitas. 
A rigor, há apenas uma alternativa (contingenciar as despesas), visto que elevar as receitas no mesmo exercício é quase impossível - os dispositivos constitucionais dificultam essa possibilidade em razão do princípio da anterioridade, exceto no caso das contribuições cujos dispositivos são outros.

Constata-se que, de forma bastante distinta à Lei 4.320/1964 (BRASIL, 1964) e à Constituição Federal (BRASIL, 1988), que enfatizam fortemente a "gestão orçamentária”, a LRF, por sua vez, volta-se à "gestão financeira” sem desconsiderar a execução orçamentária, até porque os resultados financeiros são inexoravelmente dependentes dessa execução. Em outras palavras, a LRF estabelece dispositivos de execução orçamentária, a exemplo da limitação de empenhos, cujo objetivo é convergir necessariamente a execução orçamentária com os resultados financeiros compatíveis com as metas fiscais fixadas na LDO. Essa perspectiva é absolutamente aderente aos fundamentos da LRF, que pressupõe a prevenção de riscos e a correção de desvios no sentido de garantir o equilíbrio das contas públicas.

A LRF adquire caráter bem mais dinâmico do que a Lei n. 4.320/1964 (BRASIL, 1964), cujos resultados eram apurados apenas ao final do exercício, ainda que se contemplasse a necessidade de cotas trimestrais, não tendo nenhuma meta explícita que se desejasse alcançar, assim como não havendo meios legais que obrigassem o gestor público a adequar a execução orçamentária às vicissitudes do ciclo econômico. Nessa visão, outrora se afirmava que a gestão da coisa pública era guiada quase que exclusivamente pela disponibilidade orçamentária, ignorando as disponibilidades financeiras - denominada "dominância orçamentária".

O caráter dinâmico da LRF deriva, dentre outros aspectos, da compatibilização das previsões estabelecidas na Lei Orçamentária Anual (LOA) que são meras expectativas, particularmente no caso das receitas "estimadas" para as condições do ciclo econômico. Assim, a LRF pretende efetivamente inverter a lógica anterior - denominada como dominância orçamentária -, de maneira que a execução orçamentária da despesa dependa da disponibilidade de caixa, resguardando as metas fiscais anteriormente fixadas na LDO. Nesse sentido, os relatórios e os demonstrativos de gestão fiscal exigidos na LRF cumprem a função de acompanhar e de informar, por exemplo, o desempenho da receita arrecadada vis-à-vis a receita prevista, subsidiando, assim, a programação financeira. O Quadro 1 apresenta o exposto de modo sintético. 
Quadro 1: Gestão orçamentária x gestão financeira

\begin{tabular}{|c|c|c|}
\hline & Gestão Orçamentária & Gestão Financeira \\
\hline Lógica & $\begin{array}{l}\text { Planejamento futuro da admi- } \\
\text { nistração e transparência ao ci- } \\
\text { dadão. }\end{array}$ & $\begin{array}{l}\text { Realidade econômica atual (i.e., } \\
\text { arrecadação de impostos e exe- } \\
\text { cução de despesas). }\end{array}$ \\
\hline $\begin{array}{c}\text { Instrumentos } \\
\text { normativos }\end{array}$ & $\begin{array}{l}\text { Ações na Lei Orçamentária } \\
\text { Anual, edição de alterações nas } \\
\text { autorizações da LOA, tais como } \\
\text { decretos de créditos suplemen- } \\
\text { tares, leis de crédito suplementar } \\
\text { ou especial e créditos extraordi- } \\
\text { nários. }\end{array}$ & $\begin{array}{l}\text { Definições das metas na Lei de } \\
\text { Diretrizes Orçamentárias, rela- } \\
\text { tórios de avaliação de receita e } \\
\text { despesa e decretos de contingen- } \\
\text { ciamento ao longo do ano. }\end{array}$ \\
\hline $\begin{array}{l}\text { Momento } \\
\text { de edição }\end{array}$ & $\begin{array}{l}\text { 1. Ações da LOA: enviadas pelo } \\
\text { Executivo até setembro do ano } \\
\text { anterior à execução orçamentária. } \\
\text { 2. Decretos ou projetos de lei } \\
\text { de crédito suplementar: a qual- } \\
\text { quer momento durante o ano da } \\
\text { execução orçamentária, desde } \\
\text { que haja fonte de receita para } \\
\text { tal, conforme dispõe a Lei n. } \\
\text { 4.320/1964 (BRASIL, 1964). } \\
\end{array}$ & $\begin{array}{l}\text { 1. Meta de resultado primário, } \\
\text { LDO: enviada em abril do ano } \\
\text { anterior ao exercício. } \\
\text { 2. Relatórios de receita e despe- } \\
\text { sas e decretos de contingencia- } \\
\text { mento: emitidos bimestralmen- } \\
\text { te e relacionados ao desempenho } \\
\text { econômico durante o ano (exe- } \\
\text { cução orçamentária). }\end{array}$ \\
\hline Palavra-chave & Autorização & Execução \\
\hline
\end{tabular}

Fonte: AGU (2016, p. 92).

Ainda em conformidade com os dispositivos da LRF, foi exigido, no âmbito da LDO, o Anexo de Riscos Fiscais no sentido de avaliar os passivos contingentes e outros riscos capazes de afetar as contas públicas, informando as providências a serem tomadas, caso se concretizem $\left(\operatorname{art.} 4^{\circ}, \mathbb{3} 3^{\circ}\right)$ :

As contingências passivas referem-se a possíveis novas obrigações cuja confirmação depende da ocorrência ou não de um ou mais eventos futuros, ou que a probabilidade de ocorrência e magnitude dependem de condições exógenas imprevisíveis. São também consideradas contingentes as obrigações que surgem de eventos passados, mas que ainda não são reconhecidas por ser improvável a necessidade de liquidação ou porque o valor ainda não pode ser mensurado com suficiente segurança (BRASIL, 2016c, p. 30).

Por sua vez, os riscos fiscais normalmente se classificam em duas dimensões: a) os riscos orçamentários que se relacionam a eventos inesperados, notadamente os de natureza macroeconômica (nível de atividade, taxa de juros, mercado de trabalho 
etc.), que podem afetar as estimativas de receitas e de despesas, ocasionando desequilíbrios fiscais; b) os riscos que se associam às dificuldades de refinanciamento do estoque da dívida causada, por exemplo, por eventos aleatórios e imprevisíveis no comportamento das taxas de juros e câmbio, o que pode afetar os serviços da dívida.

Reafirma-se que os dispositivos ora apresentados visam garantir o equilíbrio das contas públicas. Nessa perspectiva, a LRF também impôs parâmetros às despesas de pessoal, ao endividamento público e às inscrições em restos a pagar. Assim, determinou regras de conduta com limites quantitativos que impediam o gestor público de ir além do estipulado; estabeleceu regras de convergência, quando se ultrapassassem os parâmetros estabelecidos; e tipificou como crime de responsabilidade o descumprimento das normas estabelecidas nas leis orçamentárias².

Em relação às despesas de pessoal, os limites foram definidos como percentual da Receita Corrente Líquida (RCL), sendo 50\% para a União e 60\% para os estados e municípios, considerando, ainda, os critérios de repartição. Da mesma forma que os anexos de metas e de riscos fiscais, a verificação dos limites das despesas de pessoal é realizada quadrimestralmente por meio do Relatório de Gestão Fiscal - RGF (art. 22) e, havendo excesso para além dos limites estabelecidos, a LRF especifica as providências que deverão ser tomadas (art. 23).

De modo semelhante, os limites de endividamento das unidades federadas, exceto para a União, foram definidos como percentual da receita corrente líquida. Assim, no caso dos municípios, estabeleceu-se que o endividamento máximo não poderá exceder 1,2 vezes a RCL e, para os estados, duas vezes. $\mathrm{O}$ art. 31 estabeleceu os critérios de recondução da dívida aos limites: "[...] se a dívida consolidada de um ente da Federação ultrapassar o respectivo limite ao final de um quadrimestre, deverá ser a ele reconduzida até o término dos três subsequentes, reduzindo o excedente em pelo menos $25 \%$ (vinte e cinco por cento) no primeiro". Convém salientar que o acompanhamento dos limites fixados também é realizado quadrimestralmente pelo RGF (art. 30, $\mathbb{S} 4^{\circ}$ ).

Nesse diapasão, o resultado primário e o montante da dívida pública são dois elementos centrais na LRF, de maneira que o resultado de um só faz sentido em relação ao comportamento do outro, pois configuram relações mutuamente determinantes. Do ponto de vista macroeconômico, o resultado primário é variável primaz para garantir a sustentabilidade intertemporal da dívida pública.

O resultado primário e o montante da dívida pública são as regras fiscais com maior abrangência na LRF. Entretanto, ressalta-se que, no escopo desta, o resultado primário é exigível apenas para fins de recondução da dívida ao limite (art. $31, \mathbb{S} 1^{\circ}$, II), não sendo obrigatório quando não há excesso de dívida a reconduzir. Não se pode negligenciar o fato de que, uma vez fixado e aprovado o resultado primário

2 Ver Lei n. 10.028, de 19 de outubro de 2000, que alterou o Decreto-Lei n. 2.848, de 7 de dezembro de 1940 - Código Penal; a Lei n. 1.079, de 10 de abril de 1950; e Decreto-Lei n. 201, de 27 de fevereiro de 1967. 
no anexo de metas fiscais na LDO, fica o gestor público obrigado a cumpri-las, sob pena de responder pelo crime de responsabilidade.

Ainda no sentido de garantir o equilíbrio das contas públicas, notadamente entre a passagem do mandato do chefe do Poder Executivo a outro, a LRF buscou aprimorar os instrumentos previstos na Lei n. 4.320/1964 (BRASIL, 1964) e na Constituição Federal (BRASIL, 1988), a exemplo dos "restos a pagar". Conforme já apresentado na seção anterior, a referida lei, no art. 36, considera restos a pagar " [...] as despesas empenhadas, mas não pagas até o dia 31 de dezembro distinguindo-se as processadas das não processadas" (BRASIL, 1964). Da mesma forma, havia-se ponderado que preceito faz todo sentido, pois é impossível que todas as despesas sejam integralmente pagas dentro do exercício financeiro. Ademais, há a necessidade de apropriar a despesa na conta contábil adequada.

O problema surge porque a Lei n. 4.320/1964 (BRASIL, 1964) não definiu um limite ao fim do mandato do chefe do Poder Executivo, em que se tornou regra passar enormes montantes de restos a pagar de um mandato a outro. Em períodos de elevada inflação, isso não fazia muita diferença, pois as despesas empenhadas, podendo ou não ser liquidadas, mas não pagas, rapidamente perdiam relevância financeira; afinal, não havia nenhum mecanismo de indexação. De fato, o processo inflacionário foi um importante instrumento para garantir o equilíbrio das contas públicas por décadas, dado que as receitas, de forma geral, gozavam de algum mecanismo de indexação, enquanto as despesas fixadas apenas pelo valor nominal estavam expostas às vicissitudes da inflação corrente.

Com a estabilização monetária, o estoque de restos a pagar compromete o equilíbrio das contas públicas e, não menos importante, passa à responsabilidade do gestor público eleito um estoque de dívida (flutuante) - os chamados restos a pagar - que em nada contribuiu para formar, afetando, assim, os resultados da nova gestão. Ademais, vale lembrar que a estabilização explicitou os brutais desequilíbrios fiscais dos estados e dos municípios, os quais foram potencializados pelo declínio das receitas das esferas subnacionais. Daí emerge, inclusive, a chamada "guerra fiscal".

Nesse contexto, a LRF, no art. 42, "pretende" estabelecer parâmetros no sentido de dificultar a passagem de restos a pagar entre um mandato e outro, sendo assim fixado:

[...] é vedado ao titular de Poder ou órgão referido no art. 20, nos últimos dois quadrimestres do seu mandato, contrair obrigação de despesa que não possa ser cumprida integralmente dentro dele, ou que tenha parcelas a serem pagas no exercício seguinte sem que haja suficiente disponibilidade de caixa para este efeito. Parágrafo único. $\mathrm{Na}$ determinação da disponibilidade de caixa serão considerados os encargos e despesas compromissadas a pagar até o final do exercício (BRASIL, 2000).

Se se considerar o texto do art. 42 exclusivamente na sua "forma", é possível afirmar que o objetivo não foi alcançado. Aliás, é necessário ir além: não era 
o objetivo do legislador impor limites tão severos, pois, se assim fosse, não faria referência temporal ("nos últimos dois quadrimestres do seu mandato") e não deixaria de citar o que efetivamente interessa, ou seja, os chamados restos a pagar, em vez de se referir a "contrair obrigação de despesa". O resultado não poderia ser diferente: abriram-se enormes possibilidades de interpretação, as quais desencadearam outras demandas jurídicas.

De acordo com Alburquerque, Medeiros e Feijó (2013), dentre as diversas polêmicas geradas pelo art. 42, dada sua amplitude de interpretação, destaca-se a referência aos restos a pagar apenas dos dois últimos quadrimestres. Assim, pergunta-se: As despesas empenhadas em períodos distintos daqueles previstos podem ser deixadas para o novo mandatário? Em que momento se contrai a obrigação de despesa? Quais quesitos devem ser considerados para verificar a disponibilidade de caixa? O empenhamento no último ano de mandato pressupõe a disponibilidade de caixa?

$\mathrm{Na}$ literatura especializada, há diversas respostas que, muito raramente, convergem para algum "consenso" e, do mesmo modo, o entendimento a respeito do assunto no âmbito dos tribunais de contas também é bastante divergente. De fato, o art. 42 ampliou a discricionariedade do gestor público, pois permitiu que diversos dispositivos estabelecidos na LRF pudessem ser "flexibilizados" de alguma forma. Quando os relatórios e demonstrativos fiscais apontam, por exemplo, alguma divergência entre receita estimada e arrecadada, raramente os gestores públicos publicam os decretos de contingenciamento ("limitação de empenho") e, quando isso ocorre, diz respeito a patamares inferiores aos necessários. Sabe-se que o excesso de orçamento do exercício corrente, vis-à-vis a disponibilidade financeira, poderá ser transferido para o exercício seguinte por meio dos restos a pagar. No entanto, há de se explicar melhor porque os decretos de contingenciamento são pouco usados e os efeitos são limitados.

Pode-se contingenciar no escopo dos orçamentos públicos, independentemente da esfera, algo pouco relevante, dado que a maior parte das despesas é obrigatória em razão dos dispositivos constitucionais (aposentadorias e pensões, por exemplo), das despesas de pessoal e encargos, ou ainda das despesas vinculadas (como saúde e educação) que compulsoriamente recebem uma parte da receita arrecadada. Assim, deseja-se enfatizar que as proposições do art. $9^{\circ}$, referente à limitação de empenhos, são nulas ou têm efeitos apenas marginais.

No caso das esferas subnacionais, o problema não é diferente. Em se tratando do munícipio de Uberlândia, o art. $18, \mathbb{S} 2^{\circ}$ da Lei n. 12.231, de 5 de agosto de 2015, estabelece: "na limitação de empenho e movimentação financeira, serão adotados critérios que produzam o menor impacto possível nas ações de caráter social, particularmente nas de educação, saúde e assistência social, e na compatibilização dos recursos vinculados" (UBERLÂNDIA, 2015). Enquanto isso, em Belo Horizonte, o art. 28 da Lei n. 10.837, de 11 de agosto de 2015, mostra que não há nenhuma possibilidade de contingenciamento nas ações de caráter social: 
[...] a limitação de empenho, de que trata o art. $9^{\circ}$ da Lei Complementar Federal n. 1/2000, incidirá sobre os seguintes tipos de despesa, na seguinte ordem: I - obras estruturantes; II - serviços de terceiros e encargos administrativos; III - investimentos do Orçamento Participativo; IV - obras de manutenção que objetivam a recuperação de danos ocorridos no equipamento existente (BELO HORIZONTE, 2015).

O propósito aqui é demonstrar a rigidez das despesas orçamentárias do setor público brasileiro que restringem enormemente as possibilidades do art. $9^{\circ} \mathrm{da} \mathrm{LRF}$. É preciso compreender por qual motivo os gestores públicos passaram a usar ostensivamente o artifício dos restos a pagar.

As possibilidades de contingenciamento são bastante restritas, dada a forte rigidez das despesas públicas e, do ponto de vista político, há pouca ou nenhuma disposição para enfrentar cortes abrangentes, pois, não raro, isso compromete as alianças políticas que sustentam o governo. Assim, segue-se adiante acreditando que a expansão da atividade econômica será capaz de elevar as receitas, gerando recursos financeiros suficientes para saldar os estoques de restos a pagar, o que, a rigor, é o cenário mais improvável. Nesse espectro de possibilidades, o aumento dos restos a pagar aparece como o caminho de menor resistência, permitindo empurrar o problema para a frente sem ferir os preceitos da LRF, ao menos no curto prazo.

A expansão dos restos a pagar tem sido o instrumento mais usado pelos gestores públicos para compatibilizar o excesso de orçamento vis-à-vis as disponibilidades financeiras com as metas fiscais (resultado primário) estabelecidas na LDO. Afinal, quanto maior o montante de empenhos inscritos em restos a pagar, dada a impossibilidade de pagá-los e, concomitantemente, de cumprir o superávit primário, maior a disponibilidade financeira. Apreende-se que a inscrição de empenhos nos chamados restos a pagar é um subterfúgio amplamente empregado no âmbito da administração pública para executar orçamentos sem reciprocidade financeira para cumprir a meta fiscal (superávit primário) instituída. Dessa forma, de meros instrumentos de giro financeiro, os restos a pagar se transformaram "[...] numa fonte de financiamento indireto e, especialmente, numa forma de ocultar um orçamento paralelo para alocar, contratar e pagar gastos, notadamente no governo federal" (AFONSO, 2010, p. 383).

Não obstante se reconheça que o uso dos restos a pagar, em todas as esferas públicas, foi (e continua sendo) instrumento relevante para escapar dos dispositivos da LRF, não se pode desconsiderar que a União é, entre os entes federativos, a que mais recorreu a esse expediente. Mais surpreendente é que o aumento dos montantes de restos a pagar ocorre, por vezes, concomitante à expansão das receitas ordinárias e extraordinárias, em que se pode deduzir que as despesas cresciam em um ritmo bastante acelerado vis-à-vis as receitas. Como resultado, o equilíbrio das contas públicas e o cumprimento das metas fiscais da União eram sustentados pela elevação dos montantes de restos a pagar que, no médio prazo, não poderiam, de modo algum, continuar a crescer. 
Os relatórios da Secretaria do Tesouro Nacional (STN, 2016a) mostravam expressiva expansão dos restos a pagar como proporção do orçamento. Para se ter ideia, entre 2007 e 2014, o Governo Federal passou a recorrer a esse instrumento para acomodar a expansão das despesas e o cumprimento das metas fiscais. Não se pode associar o expediente apenas ao arrefecimento do ciclo econômico que aconteceu de forma mais intensa nos anos de 2008 (-0,2\%), 2014 (0,1\%) e 2015 $(-3,8 \%)$. Entretanto, houve momentos de forte aceleração da atividade econômica - 2007 (6,0\%), 2008 (5,0\%) e 2010 (7,6\%) -, em que se manteve a trajetória ascendente dos estoques de restos a pagar. Daí se pode inferir que é bastante temerário explicar a expansão dos restos a pagar simplesmente em virtude da reversão do ciclo econômico.

A priori, o problema não deve ser tratado apenas do ponto de vista do aumento das despesas. Torna-se imprescindível reconhecer que os resultados fiscais que cumprem importante papel no "tripé macroeconômico" passam a ser insuficientes para manter a trajetória do endividamento em patamares adequados, na perspectiva dos credores da dívida pública. Ademais, a reversão do ciclo econômico per se foi suficiente para elevar o endividamento público, associada aos efeitos da política monetária restritiva e às operações no mercado de câmbio.

O problema fiscal não deve ser entendido apenas pela expansão das despesas primárias, mas também pela forte queda da arrecadação, afetando o cumprimento das metas fiscais (superávits primários). Durante algum tempo, a expansão do ciclo econômico permitiu compatibilizar ambos os objetivos, sem que as regras orçamentárias e fiscais, ancoradas especialmente na LRF e no tripé macroeconômico, fossem flexibilizadas. No entanto, a reversão do ciclo econômico explicitou a impossibilidade de manter tais metas, em que o caminho de menor resistência foi a flexibilização das regras orçamentárias e fiscais, o que permitiu prolongar também os ganhos políticos derivados daquele arranjo.

Nesse entremeio, generalizam-se, em todas as esferas da federação, interpretações flexíveis dos diversos dispositivos da LRF, a exemplo dos aumentos dos restos a pagar. $\mathrm{O}$ art. 11 estabelece que "[...] constituem requisitos essenciais da responsabilidade na gestão fiscal a instituição, previsão e efetiva arrecadação de todos os tributos da competência constitucional do ente da federação", mas quais são os parâmetros utilizados para estimar a receita do exercício futuro? O art. 12, assim, dispõe que as previsões de receita observarão as normas técnicas e legais, além dos:

[...] efeitos das alterações na legislação, da variação do índice de preços, do crescimento econômico ou de qualquer outro fator relevante e serão acompanhadas de demonstrativo de sua evolução nos últimos três anos, da projeção para os dois seguintes àquele a que se referirem, e da metodologia de cálculo e premissas utilizadas.

Diante disso, parece que os dispositivos são claros o suficiente para dificultar manobras que possam superestimar as receitas. Mas, na prática, há uma con- 
duta diametralmente oposta aos preceitos do art. 12 da LRF, em que se adotam expectativas de crescimento do produto que nunca se realizam, destoando das previsões de mercado quando da elaboração dos projetos de leis orçamentárias. Tanto é assim que, nos meses de janeiro de cada exercício, são famosos os decretos de contingenciamento no intuito de adequar a execução da despesa às expectativas reais de arrecadação.

A rigor, as projeções das variáveis macroeconômicas são apenas uma parte da estimação da receita, em que há a necessidade de apurar outros índices, conforme especificado no art. 12, que irão influenciar o comportamento da arrecadação no exercício seguinte. O Manual de Contabilidade Aplicada ao Setor Público (MCASP), elaborado pela Secretaria do Tesouro Nacional (STN), destaca os quesitos que deverão ser utilizados:

\begin{abstract}
[...] no âmbito federal, a metodologia de projeção de receitas orçamentárias busca assimilar o comportamento da arrecadação de determinada receita em exercícios anteriores, a fim de projetá-la para o período seguinte, com o auxílio de modelos estatísticos e matemáticos. A busca deste modelo dependerá do comportamento da série histórica de arrecadação e de informações fornecidas pelos órgãos orçamentários ou unidades arrecadadoras envolvidas no processo (BRASIL, 2014, p. 55).
\end{abstract}

Infere-se que a superestimação de receitas é ato proposital, não podendo ser explicada por erros técnicos. O propósito dessa prática não é, de forma alguma, prerrogativa da União, mas de todos os entes federativos; logo, devem-se acomodar os interesses políticos que compõem a peça orçamentária, que se manifestam por meio das emendas parlamentares. De fato, a estimativa de receita não garante a realização da despesa, visto que o orçamento público é apenas autorizativo, mas há de se convir que a alocação do crédito orçamentário gera, por si só, expectativas nos diversos segmentos sociais que demandaram serviços ou projetos do Estado e que esperam que estes sejam realizados.

Não sem razão, o orçamento público perde credibilidade diante da sociedade, pois nunca se sabe o que efetivamente será realizado, notadamente, no escopo das despesas discricionárias. Há de se considerar, ainda, que essa prática conduz de modo inexorável à ampliação dos restos a pagar, no sentido de que o orçamento aprovado não encontrará reciprocidade financeira, assim como as frustrações de receitas raramente são acompanhadas pelo contingenciamento das despesas.

Constata-se, a partir do caso da União, como o excesso de orçamento conduz à ampliação dos restos a pagar, mas esse cenário é igualmente válido para estados e municípios. Em relação aos estados, os restos a pagar se tornaram o principal instrumento de "ajuste fiscal", em razão da acentuada queda da arrecadação tributária e de suas restrições em financiar as despesas com dívidas de longo prazo: 
$\mathrm{Na}$ apuração do resultado primário dos estados pelo Banco Central, pode-se constatar que os estados apresentaram melhora do resultado primário em $\mathrm{R} \$ 22,3$ bilhões ao longo de 2015 (saiu de um déficit de R\$ 13,2 bilhões em dezembro de 2014 para um superávit de R 9,1 bilhões no final de 2015). No entanto, esse resultado esconde o fato de que essa melhora ocorreu, não pelo corte de despesas, mas pela postergação dos seus pagamentos. O volume de inscrição dos restos a pagar passou de $\mathrm{R} \$ 48,2$ bilhões em 2015 para R\$ 62,9 bilhões em 2016, uma alta de R\$ 14,7 bilhões, que representa $66 \%$ da melhora do resultado primário em 2015 pela ótica de caixa. Para se ter uma ideia do montante dos restos a pagar inscritos para este ano, eles representam 1,8 vez o total de investimentos realizados em 2015 (R\$ 35 bilhões) (MACIEL, 2016, n. p.).

No que concerne aos municípios, o uso dos restos a pagar também é bastante abrangente, especialmente nos pequenos e médios municípios, cuja receita disponível, em grande medida, depende das transferências do Fundo de Participação dos Municípios (FPM), bastante sensível ao ciclo econômico. É por isso, dentre outros fatores, que:

[...] os dados revelam que cada vez mais as prefeituras têm utilizado o artifício de postergação de despesas via restos a pagar. Desde 2008, o nível de comprometimento do caixa das prefeituras com os restos a pagar do exercício anterior vem evoluindo significativamente. Em 2015, em média, as prefeituras viraram o ano com 57,6\% do caixa comprometido com despesas do exercício anterior, praticamente o dobro do observado em 2007 (30,4\%) (FIRJAN, 2016, p. 18).

Recentemente, a forte desaceleração da atividade econômica tem reduzido expressivamente a arrecadação das esferas subnacionais, mas não se pode negligenciar que, de modo semelhante à União, houve um aumento relevante das despesas primárias, a exemplo dos gastos com pessoal e encargos, o que potencializou o desequilíbrio das contas públicas. Assim, enfatiza-se que a forte recessão econômica não explica, por si só, os desequilíbrios, mas há de se considerar que o incremento das despesas primárias - de caráter continuado - em momentos de bonança também é um fator explicativo.

É fato que a LRF previu, entre vários dispositivos, instrumentos que pudessem controlar a expansão da despesa. Nessa perspectiva, a Seção I (Da geração da despesa) do Capítulo IV (Da despesa) buscou regulamentar meios necessários para obstar a expansão da despesa que pudessem ameaçar o equilíbrio das contas públicas. É por isso que o art. 16 estabeleceu:

[...] a criação, expansão ou aperfeiçoamento de ação governamental que acarrete aumento da despesa será acompanhado de: I - estimativa do impacto orçamentário-financeiro no exercício em que deva entrar em vigor e nos dois subsequentes; II - declaração do ordenador da despesa de que o aumento tem adequação orçamentária e financeira 
com a lei orçamentária anual e compatibilidade com o plano plurianual e com a lei de diretrizes orçamentárias (BRASIL, 2000).

Por exemplo, o texto da LRF não impede que o acréscimo na despesa seja superior à receita, ainda que isso ocorra por diversos exercícios. Evidencia-se que, numa conjuntura de expansão do ciclo econômico, isso pode fazer pouca diferença, mesmo que se constate que a despesa aumente em patamares superiores à receita. De qualquer maneira, os ganhos políticos e a visão a curto prazo - dominante no setor público - sobrepõem os riscos orçamentário-financeiros. Ao considerar, então, que não há impedimentos no aparato legal, o gestor público sanciona o incremento das despesas que, em grande medida, são de caráter continuado.

O problema aparece quando as receitas não só deixam de crescer, como também há redução nominal e real. Ademais, os gestores dão pouca ou nenhuma atenção ao fato de que as despesas primárias no setor público brasileiro, qualquer que seja a esfera federativa, são fortemente indexadas, acentuando os desequilíbrios das contas públicas ${ }^{3}$. Em momentos de reversão do ciclo econômico, os gastos continuam a se expandir, independentemente do comportamento das receitas. Não é por outra razão que as despesas de pessoal e os seus encargos, no caso dos estados e dos municípios, explicam a maior parte dos desequilíbrios. É o que vamos mostrar na próxima seção.

\section{Os desequilíbrios fiscais das esferas subnacionais: despesas de pessoal e endividamento público}

A remuneração dos servidores públicos não necessariamente é arbitrada pelo gestor público. Esse é o caso, por exemplo, das remunerações vinculadas ao Salário Mínimo $(\mathrm{SM})^{4}$ e dos profissionais do magistério público da educação básica, conforme a Lei n. 11.738/2008 (BRASIL, 2008), que têm o piso salarial fixado em âmbito nacional e atualizado a partir do percentual de crescimento do valor anual mínimo por aluno referente aos anos iniciais do ensino fundamental urbano (art. $5^{\circ}$, parágrafo único), que, em 2015, foi de $\mathrm{R} \$ 1.917,78$. Além disso, há outros quesitos que induzem ao crescimento da folha de pessoal, independentemente dos reajustes anuais para recomposição do poder de compra, como progressões horizontais e verticais, quinquênios, férias-prêmios etc.

Não é difícil perceber que a manutenção desse esquema exige que as receitas públicas cresçam em magnitude suficiente para sancionar o crescimento da folha de pessoal, o que se torna uma hipótese absurda. O Gráfico 1 mostra que, desde 2008,

3 O exemplo do salário mínimo e do piso nacional dos professores é o mais emblemático, sendo seus impactos mais intensos nos entes dependentes de transferências constitucionais.

4 Entre 2003 a 2015, a inflação acumulada pelo Índice Nacional de Preços ao Consumidor Amplo (IPCA) foi de 120,3\%, enquanto o aumento do SM foi de $328,5 \%$. 
acontece justamente o contrário, ou seja, a receita corrente cresce em patamar inferior às despesas de pessoal. $\mathrm{O}$ resultado dessa equação é o desequilíbrio das contas públicas, cuja amplitude só não é maior em virtude das reduções dos investimentos e do aumento dos chamados restos a pagar.

Gráfico 1: Evolução dadespesacompessoale dareceitacorrente-Ano-base2007 = 100

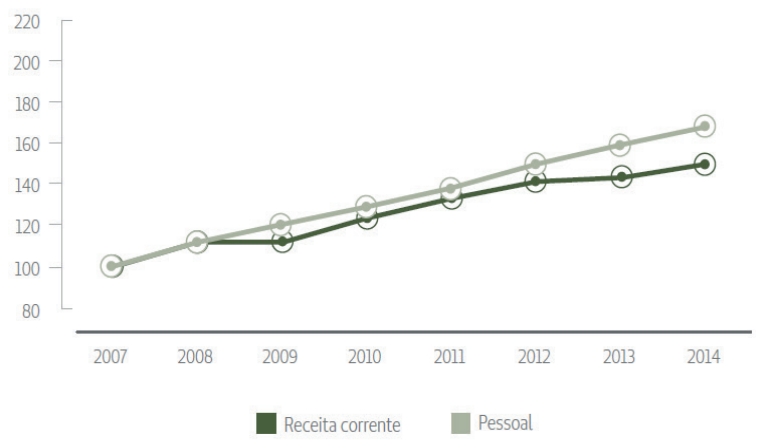

Fonte: FNP (2016, p. 101).

Tomemos como proxy da expansão da despesa de pessoal vis-à-vis às receitas o município de Uberlândia. O Plano de Carreira dos Servidores Públicos da Administração Direta do Município de Uberlândia foi aprovado pela Lei n. 11.966, de 29 de setembro de 2014, para entrar em vigor em $1^{\circ}$ de janeiro de 2015 (UBERLÂNDIA, 2014). Os efeitos do plano de carreira nas contas públicas foram devastadores, pois geraram expressivo aumento nas despesas de pessoal. Para se ter ideia, em 2014 , as despesas de pessoal somaram R $\$ 566,77$ milhões e, em 2015, alcançaram R $\$$ 777,99 milhões, gerando um acréscimo de 38,5\% (R \$ 216,21 milhões). Tal cenário foi agravado ao se constatar que, entre 2013 ( $\mathrm{R}$ 482,45 milhões) e 2014 ( $\mathrm{R}$ 566,77 milhões), as despesas de pessoal já haviam se elevado em 16,44\%. É surpreendente observar que tais aumentos não têm compatibilidade alguma com o cenário macroeconômico à época, visto que havia evidências claras de desaceleração do nível de atividade econômica. Se, ainda assim, negligenciam-se as condições macroeconômicas, não se poderia desconsiderar o comportamento da Receita Corrente Líquida (RCL) de Uberlândia.

A Tabela 1 mostra que as variações da RCL não eram suficientes para sancionar o aumento nas despesas de pessoal daquela magnitude. Mesmo considerando que a RCL, em 2014 (12,94\%), teve acréscimo bastante superior ao PIB (0,1\%), ainda assim não haveria elementos factíveis para autorizar a implantação do Plano de Cargos. Tanto é verdade que, em 2015, ano em que o plano passou a vigorar, a RCL aumentou apenas 7,65\%, enquanto as despesas de pessoal se elevaram 38,5\%. Por conseguinte, é lícito perguntar: quais parâmetros foram usados para estimar o impacto orçamentário-financeiro? 
Tabela 1: Comportamento da Receita Corrente Líquida (RCL) do município de Uberlândia (2011-2016)

\begin{tabular}{ccc}
\hline ANO & RECEITA CORRENTE LÍQUIDA & VARIAÇÃO (\%) \\
\hline 2011 & $\mathrm{R} \$ 1.109 .457 .695,06$ & - \\
2012 & $\mathrm{R} \$ 1.286 .360 .402,21$ & $15,94 \%$ \\
2013 & $\mathrm{R} \$ 1.291 .698 .019,25$ & $0,41 \%$ \\
2014 & $\mathrm{R} \$ 1.458 .838 .192,69$ & $12,94 \%$ \\
2015 & $\mathrm{R} \$ 1.570 .382 .863,98$ & $7,65 \%$ \\
2016 & $\mathrm{R} \$ 1.604 .294 .828,15$ & $2,16 \%$ \\
\hline
\end{tabular}

Fonte: Uberlândia (2011-2016).

Nota-se que, no município de Uberlândia e em quase todas as esferas subnacionais, os gestores públicos simplesmente ignoram a necessidade de estimar o impacto orçamentário-financeiro e, mesmo quando o fazem, subestimam as consequências. Dessa maneira, cumprem as exigências da LRF apenas na sua forma, ao assinar declarações de que o aumento da despesa tem adequação orçamentária e financeira. Nessa perspectiva, é temerário afirmar que a crise financeira das esferas subnacionais é derivada apenas das vicissitudes do ciclo econômico ou da concentração de recursos tributários na União, mas se deve considerar que há pouco apreço pelas regras orçamentárias e fiscais que garantem os instrumentos necessários à boa gestão pública.

Os efeitos da negligência rapidamente aparecem em fortes desequilíbrios nas contas públicas, assim como a extrapolação dos limites estabelecidos na LRF, algo que ocorreu em Uberlândia e em outros municípios. Não é por coincidência que as despesas de pessoal da cidade, em relação a RCL, aumentaram de 38,51\% (2014) para 50,97\% (2016), conforme visualizado no Gráfico 2, ultrapassando o limite estabelecido no $\mathbb{S} 1^{\circ}$, inciso II do art. 59 da referida lei (BRASIL, 2000). Tais aspectos foram ocasionados por fatores que em nada se relacionam com as condições econômicas, mas foram motivados por decisões autônomas dos gestores públicos que desconsideraram aquilo que efetivamente interessa: a disponibilidade financeira. 
Gráfico 2: Despesa total com pessoal do município de Uberlândia (em \% da RCL)

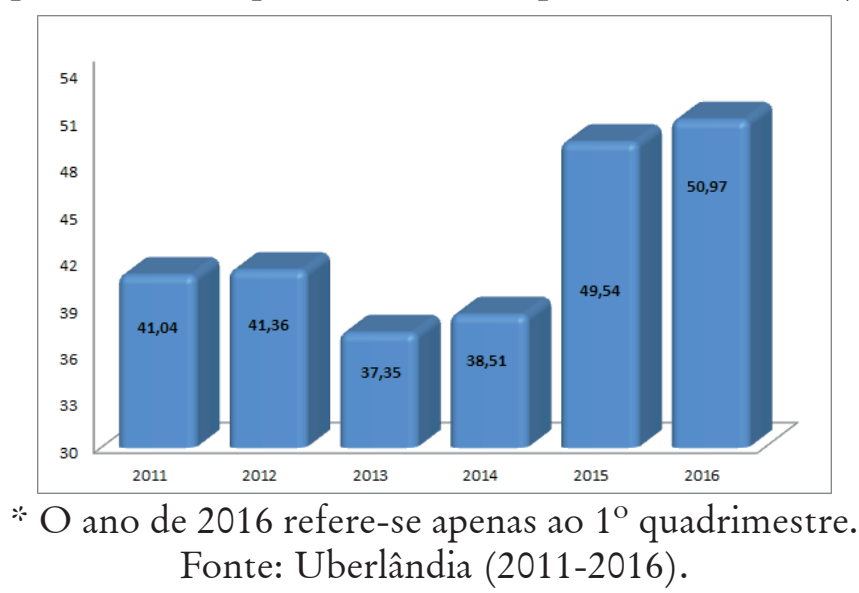

Esse problema não é prerrogativa apenas dos municípios, como também dos estados: nestes, além de as despesas de pessoal terem aumentado em patamares superiores ao PIB nos últimos anos, isso ocorreu em razão dos elevados níveis de endividamento que conduzem, por sua vez, ao maior comprometimento das despesas correntes no quesito "gastos com os serviços da dívida" (juros e encargos). No caso dos municípios brasileiros, os problemas com endividamento se associam aos grandes centros (população superior a 500 mil habitantes) $)^{5}$, e, para os demais lugares, há a função das operações de crédito para fins de investimento ou regularização de débitos junto ao Instituto Nacional de Seguridade Social (INSS), não apresentando problemas de financiamento em relação a tais aspectos.

Cabe evidenciar que os desequilíbrios nas contas públicas dos estados brasileiros são associados, principalmente, às despesas de pessoal e de endividamento, e têm amplitude muito maior do que os dos munícipios, ao menos quando vistos de maneira conjunta. No que tange aos estados, incorpora-se outro problema que não é relevante para os munícipios: as despesas com inativos ${ }^{6}$. Antes, porém, deve-se deixar claro que o excesso de gastos associados à folha de pessoal dos estados não pode, de modo algum, ser visto apenas na perspectiva da reversão do ciclo econômico, como também a partir das decisões que os governadores tomaram em períodos pretéritos e que foram motivadas, em grande medida, por perspectivas eminentemente políticas, negligenciando os impactos financeiros no médio e longo prazo e o caráter intrinsicamente cíclico da economia capitalista. Isso gera efeitos nada desprezíveis nas receitas públicas, ou seja, a redução das receitas públicas, pelo

5 A título de ilustração: das despesas globais com "juros e encargos da dívida” dos municípios brasileiros, apenas três (São Paulo, Rio de Janeiro e Belo Horizonte) responderam por 42,7\% do total.

6 De acordo com Caetano (2016), 62\% dos municípios brasileiros estão vinculados ao Regime Geral de Previdência (RGPS), sobretudo os de menor porte. No caso das capitais e dos municípios de maior porte, os servidores vinculam-se ao Regime Próprio de Previdência Social (RPPS). 
baixo nível de atividade econômica, não tem reciprocidade nas despesas de pessoal, visto que as margens de redução nesses gastos são desprezíveis ou nulas. O período recente (2015-2017) é emblemático de tal situação.

Se for tomado o período entre 2009 e 2015, as despesas de pessoal e encargos dos estados brasileiros passaram de $\mathrm{R} \$ 235$ bilhões em 2009 para $\mathrm{R} \$ 327$ bilhões em 2015, valores atualizados para $2015^{7}$, conforme visualizado no Gráfico 3. No caso das despesas com inativos e pensionistas, o crescimento é ainda maior, pois, em 2009, os gastos somavam R\$ 47 bilhões, passando para R\$ 77 bilhões em 2015.

Gráfico 3: Estados - evolução das despesas com pessoal (em bilhões de reais, 2015)

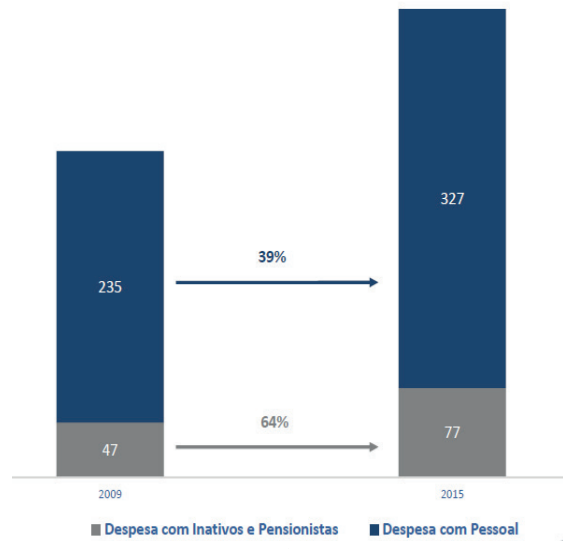

Fonte: Vescovi (2016, p. 17).

O resultado visto de forma agregada esconde as particularidades e as discrepâncias entre uma e outra unidade federativa, a despeito de que não é objeto deste estudo apresentar os detalhes dos gastos com pessoal de cada estado. De qualquer forma, é importante mencionar que, no Rio Grande do Sul, em Minas Gerais e no Rio de Janeiro, as despesas com inativos e pensionistas alcançaram, em 2015, 55,1\%, $43,6 \%$ e $45,4 \%$, respectivamente, dos gastos correntes globais.

De fato, qualquer ajuste nas despesas de pessoal (se é que existe essa possibilidade) deve ocorrer necessariamente via despesas com pessoal ativo, o que já ocorre há algum tempo, pois, na maioria dos estados, o quantitativo de servidores ativos pouco se modificou nos últimos anos. Tenciona-se compensar, ainda que parcialmente, o aumento dos servidores aposentados ao não realizar novos concursos - o resultado óbvio desse "ajuste" é a deterioração dos serviços públicos, algo real em diversas cidades brasileiras.

7 De forma distinta, as despesas de pessoal da União pouco (ou nada) se modificaram: R\$232,02 bilhões, em 2009, para e R \$243,92 bilhões, em 2015.

8 O caso do Rio Grande do Sul é emblemático: em 2015, foram aposentados 7.139 servidores públicos, mas houve apenas 579 contratações (Jornal Valor Econômico, 10 out. 2016). 
Pode-se perguntar, ainda, como vários estados chegaram a essa situação se a própria LRF impõe um limite fixado de $49 \%$ (poder executivo) para as despesas de pessoal. O fato é que diversos estados “expurgam” lançamentos (valores) das despesas de pessoal que deveriam ser contabilizadas como tal e, assim, ocultam o sentido do indicador com o objetivo de se manterem, ao menos na aparência, nos parâmetros estabelecidos na LRF. Isso ocorre, por exemplo, com o Imposto de Renda Retido na Fonte (IRRF) dos servidores públicos, os pagamentos de gratificações, a folha de pagamento de inativos e pensionistas, a mão de obra terceirizada, entre outros. Ao considerar que, em alguns estados, os "expurgos" são relevantes, chega-se a uma relação entre despesa de pessoal e receita corrente líquida meramente ilusória e de nenhum significado gerencial, conforme visto na Tabela 2.

Tabela 2: Gastos de pessoal x RCL (em \%)

\begin{tabular}{llll}
\hline ESTADOS & RGF & PAF & $\Delta \%$ \\
\hline Distrito Federal & $50 \%$ & $64 \%$ & $14 \%$ \\
Goiás & $50 \%$ & $64 \%$ & $14 \%$ \\
Minas Gerais & $58 \%$ & $78 \%$ & $20 \%$ \\
Mato Grosso do Sul & $44 \%$ & $73 \%$ & $29 \%$ \\
Paraíba & $62 \%$ & $64 \%$ & $2 \%$ \\
Paraná & $51 \%$ & $62 \%$ & $11 \%$ \\
Rio de Janeiro & $42 \%$ & $63 \%$ & $21 \%$ \\
Rio Grande do Sul & $59 \%$ & $71 \%$ & $12 \%$ \\
\hline
\end{tabular}

Fonte: Elaboração própria, a partir de Vescovi (2016, p. 17).

Finalmente, é importante averiguar o comportamento dos estados em relação aos patamares de endividamento. Nesse aspecto, há de se admitir que os incrementos do endividamento não podem, de modo algum, serem imputados apenas aos governadores, pois a União concedeu aos estados ampla margem para aumentar o endividamento via bancos públicos. Vale mencionar que essas operações favoreceram os desequilíbrios da folha de pessoal, visto que parte dos investimentos puderam ser financiados com dívidas bancárias, ampliando a disponibilidade de recursos financeiros próprios que suportaram as despesas de pessoal (STN, 2016a) - isso justifica como foi possível manter a trajetória ascendente das despesas de pessoal sem que os problemas de insuficiência de tesouraria se manifestassem. Quando o ciclo econômico se reverte e o Tesouro Nacional reduz as garantias para novos financiamentos, os problemas de caixa não mais podem ser contornados, explicitando os déficits públicos das esferas estaduais em sua amplitude.

O exposto no parágrafo acima pode ser visualizado no Gráfico 4, que mostra a evolução das receitas de operações de crédito das unidades subnacionais entre 2008 e 2015. Observa-se que, a partir de 2012, as operações de crédito se elevaram expressivamente, em virtude da ampliação das garantias concedidas pela STN, al- 
cançando, em 2013, R \$37,71 bilhões e, posteriormente, diminuindo para $\mathrm{R} \$ 20,28$ bilhões em 2015. O interregno 2013-2014 foi influenciado pelas vicissitudes do calendário eleitoral, o que explica o expressivo aumento das receitas com operações de crédito das esferas subnacionais, inclusive com a flexibilização dos critérios de concessão dos financiamentos por parte da União - esse ponto será retomado adiante.

Gráfico 4: Receitas de operações de crédito: esferas subnacionais (em bilhões de reais)

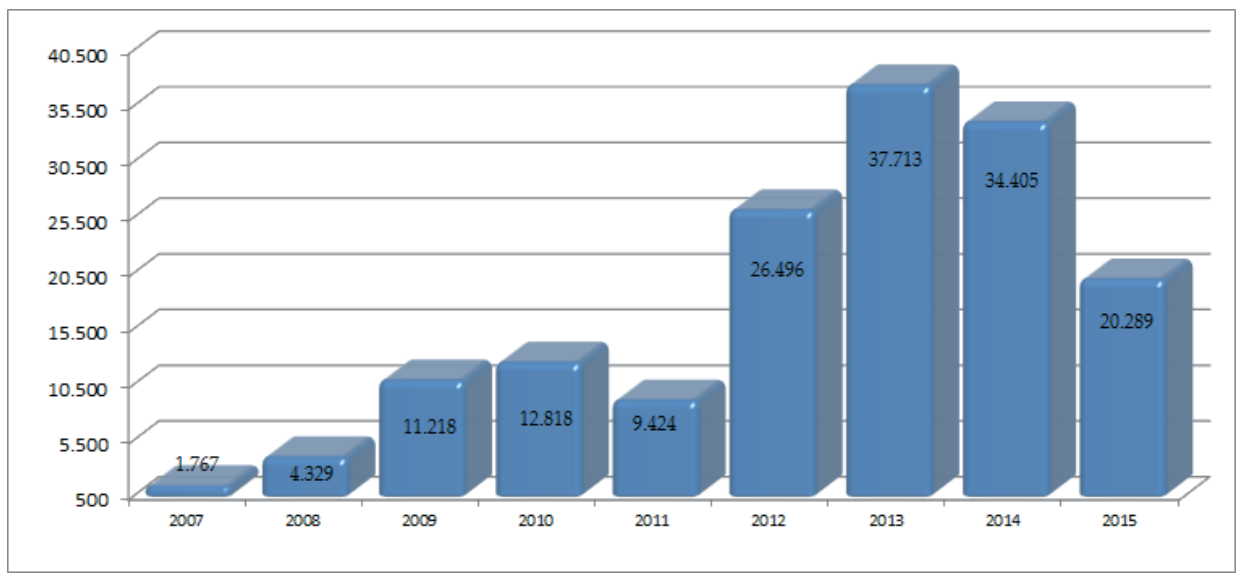

Fonte: STN (2016b, p. 21).

A partir de 2015, em razão do ajuste fiscal e das modificações no âmbito da política fiscal, a situação financeira das esferas subnacionais, especialmente os estados, deteriorou-se de maneira acelerada. Isso ocorre inter alia porque as receitas com operações de crédito se reduzem quase pela metade, restringindo as margens de manobra dos entes federados para financiar os investimentos. Logo, apenas duas alternativas estavam à disposição: financiar os investimentos com recursos próprios ou reduzir as despesas com investimentos. Não é difícil concluir que a segunda alternativa foi o caminho escolhido, simplesmente porque, naquele contexto, as disponibilidades de tesouraria já haviam encolhido em função da profunda recessão econômica - como exemplo disso, os investimentos dos estados foram de R \$ 57,5 bilhões, em 2014, para $\mathrm{R} \$ 35,8$ bilhões, em 2015. No sentido oposto, as despesas com pessoal (ativos e inativos) fortemente indexadas passaram de $\mathrm{R} \$ 289,4$ bilhões, em 2014, para R\$327 bilhões, em 2015, desempenho superior à inflação do período.

Surpreendentemente, “[...] entre 2012 e 2014, a concessão de garantia da União a operações de crédito de estados e municípios foi maior para os entes com capacidade fiscal (Capag) classificada como $\mathrm{C}$ ou D, do que para os entes com Capag A ou B” (STN, 2016b, p. 22). Confirma-se, assim, que, se houve algum critério para a concessão de financiamentos, é provável que passou ao largo dos parâmetros de avaliação de risco. Curioso que estados historicamente não bem-sucedidos em reduzir os níveis de endividamento também foram contemplados com a expansão 
das operações de crédito. Se não bastasse esse cenário, tais estados apresentavam gastos de pessoal para além dos limites fixados pela LRF - os que se enquadram nesses dois quesitos (dívida e folha) são: Rio Grande do Sul, Minas Gerais e Rio de Janeiro.

As informações da Tabela 3 incorporam, além dos estados acima citados, outros que não necessariamente apresentam dívida elevada, mas que, por outro lado, possuem elevados gastos com a folha de pessoal (ativos e inativos). De qualquer forma, comumente houve a expansão das operações de crédito, seja por intermédio dos bancos federais ou pelo endividamento externo. Não se pode esquecer que, no caso das dívidas externas, o problema das variações cambais representa riscos elevados e, novamente, Rio Grande do Sul, Minas Gerais e Rio de Janeiro usaram de maneira ampla essa modalidade de endividamento, mais que dobrando o montante da dívida externa entre 2012 e 2015.

Tabela 3: Montante de endividamento - credores selecionados (em milhões de reais)

\begin{tabular}{lcccccccc}
\hline \multirow{2}{*}{ ESTADOS } & \multicolumn{2}{c}{2012} & \multicolumn{2}{c}{2013} & \multicolumn{2}{c}{2014} & \multicolumn{2}{c}{2015} \\
\cline { 2 - 9 } & $\begin{array}{c}\text { Bancos } \\
\text { federais }\end{array}$ & $\begin{array}{c}\text { Dívida } \\
\text { externa }\end{array}$ & $\begin{array}{c}\text { Bancos } \\
\text { federais }\end{array}$ & $\begin{array}{c}\text { Dívida } \\
\text { externa }\end{array}$ & $\begin{array}{c}\text { Bancos } \\
\text { federais }\end{array}$ & $\begin{array}{c}\text { Dívida } \\
\text { externa }\end{array}$ & $\begin{array}{c}\text { Bancos } \\
\text { federais }\end{array}$ & $\begin{array}{c}\text { Dívida } \\
\text { externa }\end{array}$ \\
Distrito Federal & 815 & 646 & 949 & 688 & 1.358 & 736 & 1.845 & 1.026 \\
Goiás & 3.653 & 53 & 4.753 & 45 & 6.549 & 35 & 7.560 & 37 \\
Minas Gerais & 2.646 & 5.603 & 6.303 & 9.396 & 7.157 & 10.384 & 9.408 & 14.812 \\
$\begin{array}{l}\text { Mato Grosso do } \\
\text { Sul }\end{array}$ & 102 & 683 & 557 & 784 & 1.088 & 883 & 1.089 & 1.280 \\
Paraíba & 567 & 177 & 772 & 259 & 1.326 & 283 & 1.532 & 385 \\
\hline Paraná & 38 & 629 & 175 & 558 & 1.277 & 917 & 1.378 & 1.331 \\
\hline Rio de Janeiro & 3.941 & 5.384 & 7.708 & 7.308 & 14.104 & 9.078 & 21.035 & 14.382 \\
\hline $\begin{array}{l}\text { Rio Grande do } \\
\text { Sul }\end{array}$ & 882 & 2.906 & 1.106 & 3.541 & 1.801 & 5.463 & 1.679 & 8.043 \\
\hline
\end{tabular}

Fonte: Elaboração própria, a partir de STN (2016b).

Em consonância com às considerações expostas nos parágrafos anteriores, não há dúvidas de que os desequilíbrios das contas públicas das esferas estaduais foram induzidos, dentre outros motivos, também pelas decisões tomadas no âmbito do Governo Federal que, no afã de recuperar o nível de atividade econômica, expandiu as concessões de garantia aos estados, à revelia dos parâmetros de avaliação de risco. Isso, naturalmente, não exime os governadores de tal responsabilidade, posto que as trajetórias de endividamento e das despesas de pessoal já se mostravam insustentáveis e a manutenção desse cenário (expansão dos gastos) só poderia permanecer incólume com robustas taxas de crescimento das receitas públicas, o que à época já se mostrava improvável. 


\section{Considerações finais}

O propósito deste artigo foi mostrar que o regime fiscal brasileiro não pode ser visto apenas em uma perspectiva jurídica, sendo necessário entender o contexto das reformas liberais da década de 1990 e a criação de um ambiente macroeconômico convergente à estabilidade monetária. Isso explica porque o novo regime macroeconômico ancora-se nas seguintes premissas: câmbio flutuante, metas de inflação e superávit primário. Fixa-se, portanto, regras para a condução da política monetária e fiscal, limitando as ações discricionárias do Estado.

Assim, a Lei de Responsabilidade Fiscal deve ser vista como um conjunto de dispositivos acoplados à perspectiva macroeconômica. Sob esse viés, é importante frisar que o novo ordenamento estabeleceu regras e limites à ação do Estado, na medida em que toda e qualquer ação no âmbito do setor público subordinou-se à necessidade de gerar superávit primário suficiente para manter a trajetória sustentável do endividamento público. Além disso, a expansão do ciclo econômico, a partir de 2005, permitiu que o cumprimento das regras fixas (superávit primário, despesa de pessoal, endividamento, etc.) fosse compatível com o incremento das despesas primárias.

Desse período em diante, houve expressivo incremento das despesas primárias em consonância com as receitas, especialmente no âmbito federal. Isso ocorreu durante longo período sem que os fundamentos do Regime Fiscal fossem questionados, visto que o espaço para o cumprimento da meta fiscal e a relação dívida/PIB era compatível com as expectativas dos agentes econômicos, ou seja, o superávit primário garantia uma trajetória sustentável do endividamento público. Todavia, a reversão do ciclo econômico, associada à política monetária restritiva e à rigidez das despesas primárias evidenciaram a impossibilidade de compatibilizar as metas fiscais às ações discricionárias da administração pública.

Visto na perspectiva do setor público brasileiro, o desarranjo das contas públicas foi ainda mais intenso nas esferas subnacionais, pois as expressivas e sucessivas quedas na arrecadação, associadas à elevação das despesas financeiras e às despesas de pessoal em patamares superiores à variação das receitas, acentuaram de forma desproporcional os desequilíbrios fiscais.

\section{Referências bibliográficas}

AFONSO, J. R. R. Política fiscal no Brasil no contexto de crise. 2010. 575f. Tese (Doutorado em Desenvolvimento Econômico) - Universidade Estadual de Campinas, Campinas, 2010.

ALBUQUERQUE, C.; MEDEIROS, M.; FEIJÓ, P. H. Gestão de finanças públicas: fundamentos e práticas de planejamento, orçamento e administração financeira com responsabilidade fiscal. 3. ed. Brasília: Gestão Pública, 2013. v. 1. 
BACEN. Banco Central do Brasil. Relatório anual 2015. Brasília, 2016. Disponível em: <http://www.bcb.gov.br/?boletim2015>. Acesso em: $1^{\circ}$ nov. 2016.

BELO HORIZONTE. Lei n. 10.837, de 11 de agosto de 2015. Lei de Diretrizes Orçamentárias (LDO). Dispõe sobre as diretrizes para a elaboração e execução da Lei Orçamentária de 2016 e dá outras providências. Diário Oficial do Município, Belo Horizonte, 12 ago. 2015.

BRASIL. Advocacia Geral da União (AGU). Denúncia contra a Presidenta da República por crime de responsabilidade. Informações n. 1/2016. Brasília, $2016 a$.

. Portaria n. 40, 10 de fevereiro de 2015. Estabelece critérios e procedimentos a serem adotados pela Advocacia-Geral da União na prestação de informações sobre ações judiciais ajuizadas contra a União, suas autarquias ou fundações públicas, que possam representar riscos fiscais. Brasília, 2015a.

BRASIL. Constituição da República Federativa do Brasil. Brasília, 5 out. 1988.

BRASIL. Decreto n. 3.088, de 21 de junho de 1999. Estabelece a sistemática de "metas para a inflação" como diretriz para fixação do regime de política monetária e dá outras providências. Diário Oficial da União, Brasília, 22 jun. 1999. Disponível em: <http://www.planalto.gov.br/ccivil_03/decreto/D3088.htm>. Acesso em: 28 set. 2015.

BRASIL. Lei Complementar n. 101, de 4 de maio de 2000. Estabelece normas de finanças públicas voltadas para a responsabilidade na gestão fiscal e dá outras providências. Diário Oficial da União, Brasília, 5 maio 2000.

BRASIL. Lei n. 13.242, de 30 de dezembro de 2015. Dispõe sobre as diretrizes para a elaboração e execução da Lei Orçamentária de 2016 e dá outras providências. Diário Oficial da União, Brasília, 31 dez. 2015. Disponível em: <http://www.planalto. gov.br/ccivil_03/_ato2015-2018/2015/lei/L13242.htm>. Acesso em: 6 set. 2016.

BRASIL. Lei n. 4.320, de 17 de março de 1964. Estatui normas gerais de direito financeiro para elaboração e controle dos orçamentos e balanços da União, dos estados, dos municípios e do Distrito Federal. Diário Oficial da União, Brasília, 18 mar. 1964.

. Lei n. 9.496, de 11 de setembro de 1997. Estabelece critérios para a consolidação, a assunção e o refinanciamento, pela União, da dívida pública mobiliária e outras que especifica, de responsabilidade dos Estados e do Distrito Federal. Diário Oficial da União, Brasília, 12 set. 1997.

BRASIL. Lei n. 11.738, de 16 de julho de 2008. Regulamenta a alínea "e" do inciso III do caput do art. 60 do Ato das Disposições Constitucionais Transitórias, para 
instituir o piso salarial profissional nacional para os profissionais do magistério público da educação básica. Diário Oficial da União, Brasília, 17 jul. 2008.

.Lei n. 13.242, de 30 de dezembro de 2015. Dispõe sobre as diretrizes para a elaboração e execução da Lei Orçamentária de 2016 e dá outras providências. Diário Oficial da União, Brasília, 31 dez. 2015b.

. Ministério da Fazenda. Governo reduz em $R \$ 41,7$ bilhões o estoque de restos a pagar. 2016b. Disponível em: <http://www.tesouro.fazenda.gov.br/-/governo-reduz-em-r-41-7-bilhoes-o-estoque-de-restos-a-pagar >. Acesso em: 28 ago. 2016.

- Ministério do Planejamento. Projeto de Lei n. 2/2016-CN. Dispõe sobre as diretrizes para a elaboração e execução da Lei Orçamentária de 2017 e dá outras providências. Brasília, 2016c.

. Portaria Conjunta STN/SOF n. 1, de 10 de dezembro de 2014. Manual de contabilidade aplicada ao setor público. 6. ed. Brasília, 2014.

CAETANO, M. A. R. Solvência fiscal de longo prazo dos regimes próprios de previdência dos estados e municípios. Brasília: IPEA, 2016.

FIRJAN. Federação das Indústrias do Estado do Rio de Janeiro. Índice FIRJAN de gestão fiscal: ano base 2015. 2016. Disponível em: < http://www.firjan.com.br/ifgf/ downloads/>. Acesso em: 8 jul. 2016.

FNP. Frente Nacional de Prefeitos. Multicidades: finanças dos municípios do Brasil. 2016.

LOPREATO, F. L. C. A situação financeira dos estados e a reforma tributária. Campinas: UNICAMP, 2004. Disponível em: <http://www3.eco.unicamp.br/publicacoes >. Acesso em: 2 set. 2016.

. Aspectos da atuação estatal de FHC a Dilma. In: IPEA. Presente e futuro do desenvolvimento brasileiro. Brasília, 2014. Disponível em: <http://www.ipea. gov.br/portal/images/stories/PDFs/livros/livros/150605_livro_presente_futuro. pdf >. Acesso em: 8 jan. 2015.

. Política fiscal: mudanças e perspectivas. Boletim do Centro de Estudos de Conjuntura e Política Econômica da Unicamp, s.n., n.p, 2005. Disponível em: $<$ http://www3.eco.unicamp.br/cecon/images/arquivos/pesquisa-2003-2006/Secao_VI07-PEF.pdf $>$. Acesso em: $1^{\mathrm{O}}$ nov. 2016.

MACIEL, P. J. "Restos a pagar" crescem 31\% e explicam 2/3 a melhora do resultado fiscal dos estados em 2015. 2016. Disponível em: <http://pedrojucamaciel.com/>. Acesso em: 25 ago. 2016. 
MINISTÉRIO DA FAZENDA. Memorando de Política Econômica. 13 nov. 1998. Disponível em: <http://161.148.1.43/portugues/fmi/fmimpe01.asp >. Acesso em: 24 set. 2016.

MISHKIN, F. S. Monetary policy strategy: lessons from the crisis. National Bureau of Economic Research, Working Paper 16755, Feb. 2011. Disponível em: <https:// www.imf.org/external/np/seminars/eng/2011/res2/pdf/fm.pdf $>$. Acesso em: 15 jul. 2016.

MONTES, G. C.; ALVES, R. C. O debate acerca dos objetivos e condução da política fiscal: uma abordagem crítica à visão convencional. Economia e Sociedade, v. 21, n. 2, p. 363-386, ago. 2012.

STN. Secretaria do Tesouro Nacional. Boletim das finanças públicas dos entes subnacionais. Brasília, 2016a. Disponível em: < http://www.tesouro.fazenda.gov.br/ documents $/ 10180 / 0 /$ Boletim + de + Finan $\%$ C3\%A7as + dos + entes + subnaciona is +-+Novembro+2016/3f5b1d3a-aObd-40f8-a218-1cf44131daa8>. Acesso em: 14 nov. 2016.

STN. Secretaria do Tesouro Nacional. Relatório anual 2015: dívida pública federal. Brasília, 2016b. n. 13.

TCU. Tribunal de Contas da União. Ata n. 8, de 7 de março de 2007. Brasília, 2007.

UBERLÂNDIA. Lei n. 11.966, de 29 de setembro de 2014. Dispõe sobre o plano de carreira dos servidores públicos da administração direta do município de Uberlândia e dá outras providências. Diário Oficial do Município, Uberlândia, 30 set. 2014.

. Lei n. 12.231, de 5 de agosto de 2015. Dispõe sobre as diretrizes para a elaboração e execução da Lei Orçamentária de 2016 e dá outras providências. Diário Oficial do Município, Uberlândia, 6 ago. 2015.

. Relatório de Gestão Fiscal (RGF). Uberlândia, 2011-2016.

VESCOVI, A. P. V. J. Ajuste fiscal e relações federativas: o desafio dos estados e o papel da União. 2016. Disponível em: <http://fazenda.gov.br/centrais-de-conteudos/apresentacoes/2016/instituto-fhc-vescovi-27-09-2016.pdf/view > . Acesso em: 14 ago. 2016. 